\title{
MOTIF BURUNG ENGGANG GADING PADA PAKAIAN ADAT DAYAK KANAYATN KALIMANTAN BARAT
}

\author{
Iwan Pranoto ${ }^{*}$, Stepanus Adi Pratiswa $^{2 *}$ Nala Nandana Undiana ${ }^{3 *}$ \\ Program Studi Seni Drama Tari dan Musik Jurusan Pendidikan Bahasa dan Seni \\ Fakultas Keguruan Ilmu Pendidikan \\ Universitas Palangka Raya \\ Jl. , H Timang, Kampus UPR Tunjung Nyaho, Kota Palangkaraya 731111 \\ Kalimantan Tengah. Indonesia \\ Email: pranotoiwan@fkip.upr.ac.id, stepanusap@gmail.com,nalanandana@upi.edu
}

\begin{abstract}
Abstrak
Ragam hias merupakan sebuah ciri khas produk kebudayaan yang terdapat di berbagai daerah, seperti di Kalimantan Barat terdapatnya stilasi ragam hias burung enggang yang memiliki makna serta filosofi pandangan masyarakat setempat terhadap ragam hias tersebut dalam kehidupan sehari-harikhususnya bagi suku Dayak Kanayatn di Kabupaten Landak, Kalimantan Barat. Karya seni yang berkembang pada masyarakat ini memiliki keterkaitan dengan fenomena sosial yang banyak menggunakan bahasa simbol dan lambang dalam mengaplikasikannya pada kehidupan sehari-hari. Simbol dan lambang yang dipakai masyarakat suku Dayak Kanayatn khususnya pada pakaian adat terdapat motif hias burung enggang, yang memiliki makna-makna kehidupan, kesuburan, keberanian. Karya seni motif hias pada pakaian adat suku Dayak Kanayant mengacu pada simbol, ikon, indeks, rheme, decising, argument, qualising, sensing, dan legising serta tanda dan penanda yang digunakan dan sintakis dari objek motif burung enggang serta semantik yang terdapat dalam motif burung enggang dan pragmatik yang memberi pesan kepada pembaca. Sebuah pesan yang dimiliki oleh motif hias burung enggang pada pakaian suku Dayak Kanayatn ini akan dilihat dari beberapa bagian terdiri dari bagian kepala, badan, dan kaki, setiap bagian ini tidak lepas dari unsur-unsur seni rupa yang menjadi simbol dan makna bagi masyarakat suku Dayak Kanayatn.
\end{abstract}

Kata Kunci: dayak, motif, burung, enggang, pakaian.

\begin{abstract}
Decorative variety is a characteristic of products that exist in various regions such in Kalimantan Barat includes stylized ornamentation of burung enggang which has meaning and philosophy the views of local people on decoration in daily life, especially for Dayak Kanayatn tribe in Landak, Kalimantan Barat. Arts developed at this society hasa relationship with social phenomena that many use the language of symbols and symbols used Dayak Kanayatn tribe community specifically on traditional clothing there is a enggang gading ornamental, which is have meanings of life fertility, courage. Decoratife on traditional tribal clothing Dayak Kanayatn on symbols, icons, indeks, rheme, decising, argument, qualising, sensing, and legising, binders and markings used as well the syntax of enggang gading motif objects as well the semantics which give a message to the reader. A Message from the burung enggang ornamental on the Dayak Kanayatn tribe clothing will be, viewed from several parts consisting of the head, body, and legs, each of these parts can not be separated from fine art which are symbols for the Dayak Kayatan.
\end{abstract}

Keywords: dayak, ornament, burung, enggang, clothing.

\section{PENDAHULUAN}

Indonesia merupakan salah satu negara yang mempunyai beranekaragam bahasa, suku, budaya dan adat istiadat yang beraneka ragam, salah satu keanekaragaman tersebut terlihat dari karya seni yang diciptakan oleh masyarakat Indonesia, seperti halnya yang terdapat di Kalimantan Barat. Kalimantan Barat memiliki berbagai macam suku dan bahasa, salah satu suku yang terdapat di daerah ini adalah suku Dayak Kanayatn yang sebagian besar berdomisili di kabupaten Landak, banyak karya seni yang dapat dijumpai didaerah ini seperti seni rupa, musik, tari dan drama, yang menjadi kekhasan daerah setempat, produk seni rupa yang berkembang di daerah kabupaten Landak yaitu kerajinan.

Masyarakat Dayak Kanayatn menciptakan karya seni kerajinan sesuai dengan kebutuhan sehari-hari, adapun produk kerajinan yang diciptakan adalah pakaian adat, dimana kerajinan pakaian adat ini memiliki fungsi yang berbeda dengan pakaian pada umumnya, dan hanya digunakan pada saat kegiatan upacara adat suku Dayak 


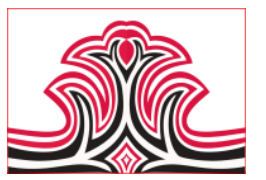

Kanayatn. Seperti yang disampaikan oleh Koentjoroningrat (2015:13) mengatakan adat merupakan wujud idel dari kebudayaan. secara lengkap wujud itu dapat kita sebut adat tata kelakuan. Hal itu dapat dbuktikan dengan adanya pakaian adat serta makna-makna tertentu dalam pengunaannya yang dapat dilihat dari motif hiasnya, salah satu ragam hias yang terdapat pada pakaian adat Dayak Kanayatn adalah motif burung enggang gading.

Berdasarkan nilai-nilai budaya yang dimiliki oleh masyarakat Dayak kanayatn, motif pada pakaian adat memberikan dampak berupa persepsi dalam kehidupan sehari-hari. Seperti yang disampaiakan oleh Pranoto (2020:104) bahwa masyarakat Dayak memiliki padagan berupa persepsi terhadap karya seni berupa makna dalam sebuah simbol yang diakitkan dengan kehidupan sosial. Dari pendapat yang dikemukan bahwa motif burung enggang pada pakaian adat Dayak Kanayatn, merupakan karya seni yang memiliki keterkaitan dengan makna-makna berupa simbol, baik itu dalam tindakan sosial, berupa komunikasi, interaksi, keyakinan, serta adat istiadat. Hal inilah yang melatarbekangi suatu kajian motif burung enggang gading pada pakaian adat Dayak Kanayatn Kalimantan Barat.

\section{KAJIAN TEORI}

Terciptanya suatu produk kesenian yang memiliki hubungan dengan masyarakat khususnya Dayak Kanayatn, membuktikan adanya nilai-nilai dan maknamakna yang tidak terlepas dari peranan ilmu semiotika. Seperti yang disampaikan oleh Zoest (1992:5) merupakan pengkajian yang berhubungan dengannya cara berfungsinya, dan hubungannya dengan tandatanda lain, pengirimannya, penerimanya oleh mereka yang mempergunakannya. Banyak sekali masyarakat tidak sadar akan semua yang dilakukan dan diucapkan tentang apa dan mengapa harus dilakukan dan diucapkan. Apabila ditelusuri dengan cermat apa yang masyarakat lakukan dan ucapkan itu banyak berhubungan dengan ilmu tanda seperti yang disampaikan oleh Budiman (2011:81) yaitu tandatanda tersebut rema (rheme), disen (dicisign) dan argument (argument), simbol, ikon, indeks, rheme, decising, argument, qualising, sensing, dan legising. Semua ini bagian dari ilmu semiotika yang menelusuri tentang berbagai bentuk makna dari dari karya seni yang dilakukan manusia. Dari pemaparan yang disampaikan bahwa setiap bagian tanda yang dimiliki pada karya seni menghasilkan makna-makna tersendiri. Dalam Etimologis pengertian simbol merupakan suatu bagian atau keadaan pemahaman terhadap objek, oleh karena itu simbol berfungsi untuk memberi nilai dalam
Gorga : Jurnal Seni Rupa

Volume 9 Nomor 2 Juli-Desember 2020

p-ISSN: 2301-5942 | e-ISSN: 2580-2380

sebuah objek yang merupakan suatu bagian penting bagi pemaknanya. Seperti yang disampaikan oleh Zoest (1993:7) Simbol memiliki makna mendalam, dari pemaparan yang disampiakn bahwa terdapatnya simbol pada karya seni yaitu suatu konsep yang paling bernilai dalam kehidupan masyarakat, oleh karena itu simbol dalam setiap daerah akan berbeda-beda sesuai dengan budaya masing-masing dan sudut pandang masyarakat contohnya di dalam sebuah kelompok masyarakat Dayak Kanayatn di Kalimantan Barat, memandang sebuah simbol tertentu yang memiliki nilai-nilai serta pesan-pesan tertentu yang bersifat tradisional apakah secara individu maupun kelompok.

Masyarakat mempunyai cara berbeda-beda untuk mengaplikasikan ilmu semiotik dalam kehidupan sehari-hari sesuai dengan budaya dan tradisinya masing-masing. Hal itu dapat dilihat dengan adanya tanda serta makna didalam sebuah karya seni, seperti yang disampaikan oleh Budiman (2011:78) menjelaskan berdasarkan objeknya tanda dibagi menjadi tiga bagian yaitu tanda atas icon (ikon) index (indeks) dan syombol (simbol), berdasarkan dari pemaparan yang disampaikan bahwa karya seni memiliki bagian-bagian yang dapat mendeskripsikan suatu makna menggunakan ilmu semiotika yaitu seperti simbol, ikon, indeks, rheme, decising, argument, qualising, sensing, dan legising.

Makna yang terdapat pada suatu karya seni tidak lepas dari suatu pengalaman pribadi, kelompok masyarkat, sehingga memiliki suatu pandangan dalam mendeskripsikan unsur-unsur visual pada karya seni. Hal itu seperti yang disampaikan oleh Pranoto (2019:149) bahwa unsur visual pada karya seni tradisi masyarkat Dayak memiliki makna yang berbeda bagi setiap kelompok masyrakat Dayak di Kalimantan baik itu tattoo, body painting, peralatan ritual, dari pendapat yang dikemukakan bahwa pemaknaan suatu karya seni yang dimiliki oleh masyrakat memiliki pandangan yang berbeda-beda, namun bagian ini tidak lepas dari nilainilai budaya berupa pesan moral serta sosial masyarakat.

Berdasarkan pembahasan para ahli, terdapatnya motif hias pada pakaian adat Dayak Kanayatn yang memiliki makna-makna yang tersirat, sehingga memunculkan suatu kajian yang dapat bahas melalui rema (rheme), disen (dicisign) dan argument (argument), simbol, ikon, indeks, rheme, decising, argument, qualising, sensing, dan legising. Hal ini memberikan pesan sosial yang berkaitan dengan kebudayaan suatu kelompok masyrakat melalui karya seni, khususnya ragam hias pada pakaian adat. 


\section{METODE PENELITIAN}

Penelitian ini menggunakan pendekatan interdisiplin dengan metode kualitatif studi kasus, dengan didukung beberapa disiplin ilmu seperti sosial, kebudayaan, estetika, dan komunikasi. Proses pengumpulan data diperoleh dari lapangan dengan cara pengamatan, wawancara, dan kedokumenan terkait serta relevan. Metode yang digunakan dalam penelitian ini yaitu kualitatif dengan pendekatan studi kasus. Dalam suatu penelitian untuk memastikan informasi berupa data yang diperoleh dari lapangan, maka diperlukan pengujian data, atau dikenal dengan istilah keabsahan data. Seperti yang disampaikan oleh Rohidi (2011: 218) bahwa keabsahan atau sering disebut kedapatpercayaan merupakan suatu informasi data yang dapat dipercaya dan masuk akal. Untuk mencapai suatu data yang terercaya maka diperlukan triangulasi data yaitu: (a) triangulasi data, (b) triangulasi sumber dan (c) tiangulasi metode. Tahapan penyajian data mengacu pada sumber yang diperoleh pada saat di lapangan, dan data yang telah menjawab rumusan masalah. Pada bagian kesimpulan dan verifikasi data, ditariklah suatu kesimpulan berdasarkan data-data yang diperoleh yang kemudian direduksi dan disajikan, berdasarkan permasalah pada penelitian.

\section{HASIL DAN PEMBAHASAN}

\section{Hasil}

\section{1). Motif Burung Enggang pada Pakaian Adat} Dayak Kanayatn

Suku Dayak merupakan sekelompok masyarakat yang sebagian besar terdapat di pulau Kalimantan, salah satunya Kalimantan Barat disana terdapat terdapat sekelompok sub-suku Dayak yaitu Dayak kanayatn merupakan salah satu suku Dayak yang tinggal dan bermukim di daerah kabupaten Pontianak, Sambas, Bengkayang dan Landak, dan kabupaten-kabupaten yang ada di Kalimantan Barat. Dalam kebudayaan Dayak Kanayatn dikenal terdapat beberapa nilai-niali tradisi yang menjadi panutan kehidupan masyarakat, salah satunya dalam bentuk karya seni rupa yaitu motif burung enggang. Masyarakat Dayak Kanayatn meyakini bahwa burung enggang merupakan hewan yang dianggap sacral karena burung enggang merupakan tipikal burung yang setia dengan pasanganya sampai akhir hayat, dimana burung ini saling melindungi dalam kehidupannya, dan burung ini juga dianggap sebagai jelmaan dari paglima perang suku Dayak.

Ornament merupakan komponen produk seni yang ditambahkan dan dibuat untuk tujuan sebagai hiasan, berdasarkan dari pengertian itu ornamen merupakan penerapan hiasan pada suatu produk agar lebih indah dan menarik. Seperti yang dikemukakan oleh Sunaryo (2009:4) bahwa ornamen adalah pola hias yang dibuat dengan digambar, dipahat, dan dicetak, untuk mendukung meningkatnya kualitas dan nilai pada suatu benda atau karya seni. Kehadiran ornamen tidak hanya semata sebagai pengisi bagian kosong tanpa arti, bermacam bentuk ornamen sesungguhnya memiliki beberapa fungsi yakni fungsi murni estetis, simbolis, teknis. Hal ini merupakan suatu tanda yang memiliki makna, seperti yang disampaikan oleh Dillistone (2002:17) bahwa tanda sebenarnya dapat dijumpai dalam kehidupan sehari-hari seperti, ketika berbicara, tersenyum, cemberut, dan diam serta simbol tertentu . Dari pendapat yang dikemukaan motif hias burung enggang memiliki makna serta nilai-nilai berupa pesan sosial pada masyarakat Dayak Kanayatn.

Motif hias burung enggang pada pakaian adat masyarakat Dayak Kanayatn dapat dianalisis dengan menggunakan dengan mengamati pola serta warna yang digunakan untuk mewakili makna-makna tertentu dan tempat peletakan motif burung enggang pada pakaian adat Dayak Kanayatn. Motif tersebut mempunyai tanda dan acuan tanda atau objek dan pengguna tanda. Pada bagian motif burung enggang bahwa tanda merupakan konsep utama yang dijadikan sebagai bahan analisis dimana di dalam tanda terdapat makna sebagai bentuk interpretasi pesan yang dimaksud.

Secara sederahana, tanda cenderung berbentuk visual atau fisik yang ditangkap oleh manusia sedangkan acuan tanda atau objek merupakan konteks sosial yang dalam implementasinya dijadikan sebagai aspek pemaknaan atau yang dirujuk oleh tanda tersebut dan Pengguna tanda (interpretant) merupakan konsep pemikiran dari orang yang menggunakan tanda dan menurunkannya kesuatu makna tertentu atau makna yang ada dalam pemikiran seseorang tentang objek yang dirujuk sebuah tanda. Hal itu meliputi bagian dari struktur bentuk motif hias enggang yang ada pada pakaian adat Dayak.

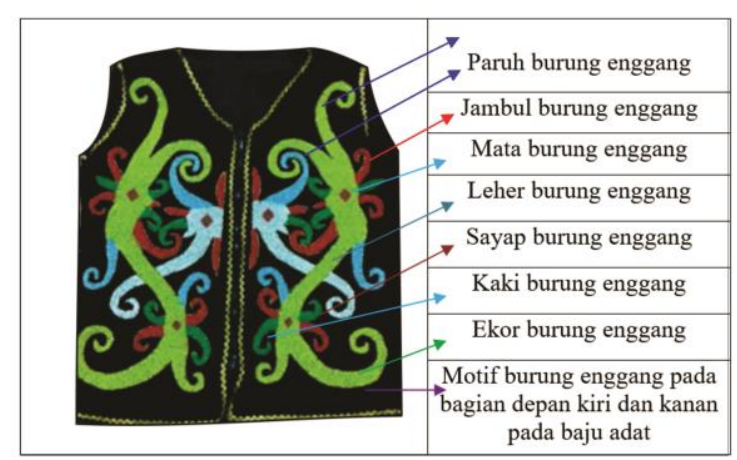

Gambar 1. Pakaian Adat Dayak (Sumber: Iwan Pranoto, 2019) 
2. Pembahasan

1). Pembagian Struktur Bentuk Motif Enggang Gading pada Pakaian Adat Dayak Kanayatn.

Terdapat beberapa pembagian pada motif hias burung enggang gading yang ada pada pakaian adat Dayak Kanayatn di Kalimantan Barat, bagian dari motif ini memiliki struktur anatomi burung enggang yang di stilasi, meliputi paruh, jambul, mata, leher, sayap, kaki dan ekor. Hal ini tidak lepas dari unsur-unsur visual yang memberikan pesan serta makna-makna dalam memahami motif ini, yang kemudian akan dibahas pada setiap bagian bentuk motif berikut;

\section{(1). Paruh Burung Enggang}

Pemaknaan simbolik sebagai tanda yang digunakan untuk bertutur dalam bahasa, khususnya dalam kehidupan, bagaimana menggunakan bahasa yang baik, sopan, tegas, jujur dan bijaksana dalam berbicara, sebagai masyarakat Dayak Kanayatn selalau diminta untuk tidak berbicara sembarangan atau tidak bertutur kata yang membuat orang lain merasa sakit hati. Paruh burung enggang ini yang dibuat pada motif berwarna kuning dan dianggap sebagai tanda kesiapan atau siaga, sedangkan pada bagian bawah berwarna terang/putih diartikan sebagai kehalusan, kelembutan, kedamaian, dan kesucian. Motif mulut burung enggang ini terbuat dari bahan kain yang kemudian dipotong mengikuti pola paruh burung enggang.

\section{(2). Jambul Burung Enggang}

Tanda suatu kedudukan atau pangkat yang dimiliki seseorang, dalam lingkungan keluarga dan masyarakat setempat. Motif pada jambul pada burung enggang ini berwarna merah yang diartikan sebagai tanda keberanian dalam mengemban tugas atau memimpin, motif ini berbentuk lengkungan seperti mahkota dan terbuat dari kain berwarna merah.

\section{(3). Mata Burung Enggang}

Tanda dari lambang dari kesiap siagaan dalam bekerja, mengamati, dan ketelitian dalam berburu. Mata ini berbentuk lingkaran yang berwarna gelap terbuat dari bahan kain yang dijahi sehingga membentu satu kesatuan dengan bentuk motif lainnya.

\section{(4). Leher Burung Enggang}

Tanda yang diartikan sebagai dari penyambung nafas kehidupan, atau diartikan sebagai penyambung hubungan atara pemimpin dengan bawahan, kepala suku dengan masyarakatnya, atau jubata (Tuhan) dengan umatnya.

\section{(5). Sayap Burung Enggang}

Tanda dari kekuatan dan kekompakan yang dimiliki oleh masyarakat Dayak Kanayatn, khususnya dalam melindungi kelompoknya dari serangan-serangan musuh, dengan adanya motif hias sayap burung enggang ini membuktikan adanya persatuan antara setiap daerah masyarakat Dayak Kanayatn.

\section{(6). Ekor Burung Enggang}

Tanda dari kesetiaan masyarakat Dayak Kanayatn dengan pemimpin, alam, dan jubata (Tuhan).

\section{(7). Kaki Burung Enggang}

Tanda dari kemampuan dalam bekerja masyarakat Dayak Kanayatn khususnya utuk memenuhi keperluan hidup sehari-hari.

\section{(8). Letak Motif Burung Enggang}

Bagian depan baju adat Dayak Kanayatn sebagai tanda dari sikap-sikap kehidupan orang Dayak Kanayatn, dalam memimpin (ritual, keluarga, masyarakat), berani dan bersatu dalam menghadapi setiap permasalahn hidup (perang), bersikap baik dengan siapun dan saling menolong, tidak merugikan antar sesama manusia, dan mampu dalam mengemban tanggung jawab dalam kehidupan. Motif burung enggang ini memiliki warna kuning, abu-abu, coklat tua, dan merah yang dibuat dari bahan kain dengan pola stilasi burung enggang, kemudian motif tersebut dijahit pada permukaan baju adat Dayak Kanayatn sebelah kiri dan kanan. Pakaian adat masyarakat Dayak Kanayatn hanya digunakan pada kegiatan-kegiatan tertentu seperti, naik dango, baremah.

2). Tingkatan Pemahaman Pemaknaan Motif Hias Burung Enggang pada Masyarakat Dayak Kanayatn

Sesuai dengan tingkat pemahaman dan keberlakuan tanda yang berkaitan dengan tingkat, seperti yang disampaikan oleh Berger (2010:66) bahwa terdapat pengelompokan tingkatan tanda qualising, sinsing, legising. Dari pendapat yang dikemukakan bahwa upaya manusia dalam memahami fenomena sosial masyarakat Dayak Kanayatn di Kalimantan Barat, khususnya terlihat pada motif hias burung enggang pada pakaian adat dapat dilihat melalui tingkatan dari tanda, melalui makna.

Kepertamaan (qualisign) yaitu Tingkatan pemahaman dan keberlakuan yang bersifat "kemungkinan, perasaan atau masih potensial".

Kekeduaan (secondness): sinsign (singular sign) Tingkat

pemahaman dan keberlakuan yang sudah"berkonfront asi/berhadapan dengan kenyataan". 
Keketigaan (thirdness); legisign (lex; hukum) Tingkat pemahaman dan keberlakuan yang sudah bersifat "aturan atau hukum atau sudah berlaku umum".

Dari tingkatan pemahaman yang dikemukakan oleh charles sanders pierce yang didalamnya terdapat qualisign, singsign dan legisign digunakan untuk menganalisis motif burung enggang gading pada pakean adat suku Dayak Kanayatn di Kalimantan Barat adalah sebagai berikut.

Quallsign dari motif burung enggang pada pakaian adat suku Dayak Kanayatn: motif burung enggang yang terbuat dari kain yang berwarna merah, kuning, abuabu dan coklat tua, yang kemudian dibentuk pola stilasi burung enggang, kemudia dipotong mengikuti pola yang bebrentuk paruh, jambul, mata, leher, sayap, kaki dan ekor, kemudian di jahit pada permukaan pakaian adat Dayak Kanayatn sebelah kiri dan kanan, setiap pla motif tersebut diletakkan sesuai dengan warna pada yang mewakili bagian-bagian dari burung enggang.

Singsign dari motif burung enggang pada pakaian adat suku Dayak Kanayatn: motif burung enggang pada pakaian adat digunakan pada kegiatan upacara-upacar tertentu seperti naik dango, baremah.

Legisign dari motif burung enggang pada pakaian adat suku Dayak Kanayatn: sebagai tanda dari sikap-sikap kehidupan orang Dayak Kanayatn, dalam memimpin (ritual, keluarga, masyarakat), berani dan bersatu dalam menghadapi setiap permasalahn hidup (perang), bersikap baik dengan siapun dan saling menolong, tidak merugikan antar sesama manusia, dan mampu dalam mengemban tanggung jawab dalam kehidupan.

\section{3). Pembagian Objek Tanda Motif Burung Enggang Gading pada Masyarakat Dayak Kanayatn}

Berdasarkan objek tanda dibagi tiga yaitu Ikon, Indek dan Simbol. kemudian digunakan untuk menganalisis motif burung enggang gading pada pakean adat suku Dayak Kanayatn yang ada di Kalimantan Barat adalah sebagai berikut.

Icon (ikon) sebuah motif burung enggang gading pada pakaian adat suku Dayak Kanayatn di Kalimantan Barat.

Index (indeks) sebuat tanda motif burung enggang gading yang dibuat dari bahan kain yang berwarna kuning, merah, coklat tua dan abu-abu, kemudian motif tersebut dipasang pada bagian kiri dan kanan pada pakean adat suku Dayak Kanayatn dengan cara dijahit.

Syombol (simbol) sebuah tanda motif burung enggang gading pada pakain adat suku Dayak Kanayatn, setiap bagian dari motif burung enggang gading memiliki pandanagan-pandangan tertentu khususnya dalam kehidupan, mulai dari paruh, jambul, mata, leher, sayap, kaki, ekor dan warna pada kain yang digunakan untuk membuat motif, pandangan motif ini dirangkum dalam satu kesatuan karena selalau memiliki keterkaitan yaitu sebagai bentuk dari kesetiaan masyarakat Dayak Kanayatn dalam mengemban jabatan, keluarga, masyarakat, kepada pimpinan, alam dan kepada jubata (Tuhan), dimana kesetiaan itu bisa berbentuk kejujuran, kekompakan, kemampuan dalam melindungi keluarga dalam perperangan.

Sesuai dengan trikonomi pada tanda yang telah dibagi dengan hakikat interpretannya yaitu rema (rheme), suatu tanda yang tidak betul dan tidak salah, tanda disen (dicent sign/dicisign) adalah tanda eksistensi aktual suatu tanda faktual yang biasanya berupa proposisi. Seperti yang disampaiakan oleh Barthes, $(2012 ; 25)$ bahwa argument (argument) adalah tanda "hukum" atau kaidah satu tanda nalar yang didasari oleh leading principle yang menyatakan bahwa peralihan dari premis-premis tertentu kepada kesimpulan tertentu adalah cenderung benar. Dari pendapat yang dikemukakan akan digunakan untuk melihat tanda pada yaitu motif burung enggang gading pada pakaian adat suku Dayak Kanayatn di Kalimantan Barat.

Rema (rheme) tanda pada motif pakaian adat suku Dayak Kanyatan di Kalimantan Barat yang dipasang pada bagian tertentu dengan pola yang berwarna-warni, sebagai tanda suatu cirri khas budaya yang ada di Kalimantan Barat.

Disen (dicent sign/dicisign) tanda yang menunjukan motif enggang gading dapat digunakan pada produk kesenian yang ada di Kalimantan Barat, sebagai tanda yang memiliki pesan sosial bagi masyarakat Dayak Kanayatn.

Argument (argument) tanda yang menunjukan motif burung enggang gading yang dibuat menggunakan bahan kain berwarna merah, kuning, coklat tua dan abu-abu, yang kemudian pola tersebut dipotong sesuai bentuk stilasi burung enggang gading, setelah itu setiap bagian disatukan dengan cara menjahi kepada pakean adat suku Dayak Kanayatn sebelah kiri dan kanan. Motif ini memiliki pesan dalam kehidupan masyarakat suku Dayak Kanayatn, setiap bagian memiliki makna yang kemudian dirangkum menjadi satu kesatuan, karena setiap bagian memiliki keterkaittan, yaitu sebagai bentuk dari kesetiaan masyarakat Dayak Kanayatn dalam mengemban jabatan, keluarga, masyarakat, kepada pimpinan, alam dan kepada jubata 
(Tuhan), dimana kesetiaan itu bisa berbentuk kejujuran, kekompakan, kemampuan dalam melindungi keluarga dalam perperangan, serta adil antara sesama manusia yang ada di sekitarnya.

\section{KESIMPULA DAN SARAN}

\section{Kesimpulan}

Kebudayaan yang berkembang di Indonesia merupakan bentuk dari munculnya nilai-nilai kreativitas setiap daerah, salah satunya terlihat pada motif burung enggang gading pada pakaian adat suku Dayak Kanayatn di Kalimantan Barat. Munculnya kretivitas didaerah ini beriringan dengan nilai-nilai kebudayaan yang masih memegang suatu tanda dengan maknamakna tertentu, makna dari motif burung enggang gading ini memiliki kaitannya dengan kehidupan sehari-hari dimana setiap bagian dari motif tersebut memiliki arti-arti tertentu, seperti paruh burung, jambul, mata, leher, sayap, kaki, ekor dan terdapat warna pada setiap bagian kain yang digunakan untuk membuat motif burung enggang dan kemudian motif tersebut dijahit pada bagian kiri dan kanan pakaian adat Dayak Kanayatn.

Pada bagian motif burung enggang gading pada pakaian adat suku Dayak Kanayat di Kalimantan Barat terdapat tanda sebagai ground dan dari trikotomi yang dibagi menjadi beberapa bagian yaitu qualisigns, sinsigns, legisigns, kedua yaitu ikon, indeks, simbol, dan yang ketiga yaitu rema, disen dan argumen. Setiap point-point yang mengungkapkan bagian-bagian pada karya seni tersebut dengan cara mendeskripsikan yaitu Quallsign dari motif burung enggang pada pakaian adat suku Dayak Kanayatn: motif burung enggang yang terbuat dari kain yang berwarna merah, kuning, abuabu dan coklat tua, yang kemudian dibentuk pola stilasi burung enggang, kemudia dipotong mengikuti pola yang bebrentuk paruh, jambul, mata, leher, sayap, kaki dan ekor, kemudian di jahit pada permukaan pakaian adat Dayak Kanayatn sebelah kiri dan kanan, setiap pla motif tersebut diletakkan sesuai dengan warna pada yang mewakili bagian-bagian dari burung enggang. Motif ini memiliki pesan dalam kehidupan masyarakat suku Dayak Kanayatn, setiap bagian memiliki makna yang kemudian dirangkum menjadi satu kesatuan, karena setiap bagian memiliki keterkaittan, yaitu sebagai bentuk dari kesetiaan masyarakat Dayak Kanayatn.

\section{Saran}

Dengan adanya analisis ini dapat menjadi pengembangan serta ilmu pengetahuan tentang budaya khususnya karya seni rupa, di setiap daerah yang ada di
Gorga : Jurnal Seni Rupa

Volume 9 Nomor 2 Juli-Desember 2020

p-ISSN: 2301-5942 | e-ISSN: 2580-2380

Indonesia. Hal ini juga dapat menjadi pengembangan dalam penciptaan karya seni, kajian seni, serta proses pembelajaran yang di muat dalam institusi pendidikan secara formal dan nonformal.

\section{DAFTAR RUJUKAN}

Barthes, Roland. (2012). Elemen-elemen Semiologi. Yogyakarta: IRCiSOd

Berger, Asa Arthur. (2010). Pengantar Semiotik, Yogyakarta: Tiara Wacana.

Budiman, K. (2011). Semiotika Visual. Yogyakarta: Jalasutra.

Dillistone, F.W. (2002). The Power Of Symbols. Yogyakarta: Kanisius

Koentjaraningrat, 2015. Kebudayaan Mentalis Dan Pembangunan, Jakarta: PT Gramedia Pustaka Umum

Pranoto, I., Siahaan, V. D., Triyanto, T., \& Rohidi, T. R. (2020). The Ceramics of Singkawang: Dayak Kanayatn's Cultural Perceptions in Kalimantan Barat. Mudra Jurnal Seni Budaya, 35(1), 103111.

Pranoto, Iwan. (2019). Unsur Visual: Penciptaan Body Painting Mahasiswa Sendratasik Universitas Palangka Raya. Prosiding. Seminar Nasional Pendidikan Pascasarjana Universitas Palangka Raya: Hal 145-154

Rohidi, Tjeptjep Rohendi. (2011). Metodologi Penelitian Seni. Semarang: Cipta Prima Nusantara.

Sunaryo, A. (2009). Ornamen Nusantara. Jakarta: Gramedia.

Zoest, Aart Van dan Sudjiman Panuti. (1992). Serba Serbi Semiotika. Jakarta: Gramedia Pustaka Utama.

Zoest Art Van. (1993). Semiotika. Jakarta: Yayasan Sumber Agung. 